\title{
Extent of Disclosure in the Annual Reports of Malaysian Federal Statutory Bodies
}

\author{
Nur Barizah Abu Bakar \\ Assistant Professor, College of Business, Alfaisal University, Riyadh \\ Kingdom of Saudi Arabia; Email: nbakar@alfaisal.edu
}

\author{
Zakiah Saleh \\ Associate Professor, Department of Accounting, Faculty of Business and Accountancy \\ University of Malaya, Kuala Lumpur, Malaysia; Email: zakiahs@um.edu.my
}

\section{Doi:10.5901/mjss.2016.v7n2p158}

\begin{abstract}
Federal statutory bodies in Malaysia are public sector organizations that adopt a corporate style-management, where annual report serves as an important accountability medium. This study aimed at determining the extent of accountability information disclosed by these bodies in their annual reports. Using a disclosure index derived from the public accountability paradigm, 106 annual reports were analysed. Findings suggest that these bodies provided a moderate level of disclosure in their reports. The highest disclosure was found in the Performance category while the least disclosure was detected in the Governance category. In this regard, more efforts are required in ensuring that the annual reports of such federal statutory bodies serve more effectively as a mechanism by which public accountability agenda can be achieved and fulfilled.
\end{abstract}

Keywords: Accountability; Disclosure; Public Sector; Reporting; Statutory bodies

\section{Introduction}

In many parts of the world, semi-governmental bodies are created because respective ministerial departments in various countries are not capable of handling certain public sector functions particularly those related to the commercial fields (McCrae and Aiken, 1988). Likewise, the Malaysian federal statutory bodies (MFSB) were established as semigovernmental agencies for the purpose of acheiving specific governmental objectives. The MFSB are awarded greater autonomy than governmental departments. They undertake various nature of activities including education, regulatory and socio-economic affairs. Many financial, management and accountability issues surround the MFSB, with a quarter of them suffering from deficits. In relation to reporting, the Malaysian Treasury has issued a circular, Treasury circular (TC) no. $4 / 2007$, which guides the MFSB on the preparation and presentation of their annual reports and financial statements.

Based on the above, it seems apparent that the MFSB have to provide an extensive accountability and obligation to the wider public. This need is attributed largely to the impact they have on the lives of many citizens - both as the provider of large amounts of public resources consumed and as service recipients. Thus, it is very relevant and important that the MFSB discharge their public accountability. However, with the autonomy granted to the MFSB, there have been concerns about their ability to maintain a balance between discharging public accountability and acting independently. Guthrie (1993), for example, commented that the traditional public sector accountability is likely to be compromised when the corporate form is used in public sector agencies, as greater attention is given to its commercial rather than its social objectives. This issue represents the extra challenge faced by such types of bodies, particularly in their duty of discharging public accountability.

In looking at public sector reforms and New Public Management (NPM) ${ }^{1}$, several authors such as Patrizio (2010) noted that annual report disclosures, as an NPM strategy, can be used by public sector bodies to enhance their public accountability. This is because annual reports are regarded as the main medium of disseminating information to stakeholders (Wei et al., 2008). Based on this, disclosures in MFSB annual reports can thus be used as a valuable tool in assessing the level of public accountability discharged. Consistent with the public accountability paradigm as propagated

${ }_{1}^{1}$ NPM, according to Hood (1995) is a suite of changes to public sector management as a result of two doctrines, namely: (i) that the public and private sectors should be made less separable by aligning the private sector with the public sector, and, (ii) that rules within the public sector should be lessened so as to increase managerial discretion. 
by authors such as ljiri (1983), this present study contends that MFSB annual report disclosures must address multiple information dimensions including financial, performance, governance, sustainability, intellectual capital and others, all of which have been referred to in literature, as accountability disclosure. This study is motivated by the need to determine the extent of accountability disclosures provided by the MFSB in their annual reports. The outcome of this study will be helpful in evaluating public accountability discharged and will enable public sector practitioners to improve their level of public accountability discharged by practising wider disclosures in their external reports. Further, the outcome may add to the existing knowledge of disclosure practices made by public sectors in developing countries. This is because prior studies tend to focus on developed nations only. Goddard (2010) mentioned the importance of the insight into public sector disclosure practices in developing nations. In this regard, it is even more important than those vibrant research conducted in developed nations.

\section{Literature Review}

The importance of accountability in the public sector has been summarised by Samaratunge et al. (2008) who stated that the lack of accountability makes a state weak and its public management system dysfunctional. As agents entrusted with public resources, public organisations must be transparent on their activities and performance. Their accountability must be revealed and rightly assessed by stakeholders (Abu Bakar and Saleh, 2015; Abu Bakar et al., 2011). Transparency, disclosure and accountability are, in fact, interrelated concepts where transparency refers to voluntary disclosure (Ho and Shun Wong (2001). It is the key principle of accountability. The link between disclosure and accountability is well noted by many including Dixon et al. (1993) and Ferlie and Pollitt (2005) who agreed that a comprehensive public disclosure of information by public bodies is the main gateway to provide improved and wider accountability.

This concept of comprehensive disclosure is, in fact, consistent with the public accountability paradigm which addresses the widespread demand for greater accountability of public institutions and officials. The paradigm recognises the entitlement by a diverse group of stakeholders to information. Based on this paradigm, a valuable annual report would include a wide range of summarised, relevant information in a single document that enables stakeholders to obtain a comprehensive understanding of [an entity's] objectives and performance in financial and non-financial terms (Coy et al., 2001). Further, the comprehensive disclosure is important because traditional financial reporting measures had been inadequate in providing a complete account of business and governmental activities (Marcuccio and Steccolini, 2009). As part of the public sector reform process which pushes for greater accountability and external disclosure (Marcuccio and Steccolini, 2005), public sector reporting needs to be consequently reformed and this can be done by introducing greater disclosures.

Studies which address this need for comprehensive disclosures covering many different aspects of reporting have been using terms such as accountability disclosure/reporting to represent this kind of disclosure, a move that is consistent with the public accountability paradigm. Predominantly, such studies were conducted in higher educational institutions in developed countries (e.g. Coy and Dixon, 2004; Coy et al., 1993; Dixon et al., 1991; Nelson et al., 1997). Banks et al. (1997), for example, assessed disclosures in the 1992 to 1994 annual reports of universities in England, Wales, and Northern Ireland. They found that there was a lack of quantity or quality disclosure. They also reported that there was no statistically significant change throughout the years. Later, Nelson et al. (2003) tracked the Canadian universities' annual report disclosure from 1988 to 2000. They also observed very little change in the accountability disclosures from then until 1997. In Malaysia, as a less developed country, Ismail and Abu Bakar (2011) had evaluated the extent of accountability disclosure in the annual reports of 11 Malaysian universities. Their study revealed that accountability disclosure appeared higher in established universities' group as compared to new universities. In their latter study, Ismail and Abu Bakar (2015) evaluated the compliance of Malaysian public universities' annual report with the Malaysia government Treasury Circular no. 4/2007 (TC4/2007) in disclosing accountability information. They noted that public universities have not fully complied with the minimum disclosure requirements and that the degree of accountability information disclosure is lower. Additionally, unlike in their previous study, the established universities group also subscribed to a lower degree of compliance in the minimum disclosure requirements as compared to new universities.

All the abovementioned studies examined disclosures of universities. Few studies focused on accountability disclosures in other settings. Among these few were Ryan et al. (2002) and Blanco et al. (2011) who studied Australian and Canadian local governments' annual reports respectively. Herawaty and Hoque (2007) focused on Australian governmental departments.

Alongside these studies, some focused on public sectors but they were confined towards assessing only one aspect at a time for instance, financial (e.g. Banks and Nelson, 1994), governance (e.g. Ryan and $\mathrm{Ng}, 2000$ ), performance (e.g. Boyne and Law, 1991), sustainability (e.g. Marcuccio and Steccolini, 2005) and intellectual capital (e.g. 
Schneider and Samkin, 2008) reporting only. The above facts also apply to studies on semi-governmental bodies such as statutory authorities in Australia, executive agencies in the UK and MFSB in Malaysia. These studies appear to focus on specific aspects of reporting particularly, on performance reporting (e.g. Hyndman and Andersen, 1995; Hyndman and Anderson, 1998; Janet, 2006; Rutherford, 2000; Taylor, 2006), financial (i.e. Pendlebury et al., 1994) and governance reporting (i.e. Ryan and Ng, 2000). None has so far studied accountability disclosures. These specific reporting studies, although useful in providing some insights to specific aspects of reporting, may not be sufficient enough to allow for a comprehensive assessment of the level of public accountability discharged by public entities.

Nevertheless, despite the scope of reporting covered by these public sector literatures, the results found have generally been less than encouraging. Blanco et al. (2011) and Banks et al. (1997) reported an overall low disclosure index on information published in the annual reports of Canadian local governments and universities in England, Wales, and Northern Ireland, respectively. More specifically, certain disclosure areas such as human resources and asset management showed low levels of disclosure, as reported by Herawaty and Hoque (2007) and Schneider and Samkin (2008). Similarly, studies on semi-governmental bodies have generally shown a lack of disclosure. Hyndman and Andersen (1995) and Hyndman and Anderson (1998) reported that majority of the UK executive agencies provided little or no performance information. Ryan and $\mathrm{Ng}$ (2000) showed that governance disclosure of several Queensland statutory bodies were minimal. This lack of disclosures raises the issue of the level of accountability discharged by such bodies in general. More specific to this research, it is noted that very little studies have been done on MFSB annual report disclosures. Other than the study conducted by Ismail and Abu Bakar $(2011,2015)$ who studied only universities, which is only one of the several types of MFSB, two relevant but unpublished studies were those done by Azis (2008) and Abu et al. (2012). While Abu et al. (2012) evaluated only mandatory disclosure, Azis (2008) went a step further to evaluate some performance items of the disclosure. Azis' (2008) study, however, only covered half of the existing MFSB. These two studies apparently, do not assess accountability disclosure as both reported moderate levels of disclosure.

From the preceding findings, it is clear that studies on accountability disclosure in public sectors are lacking in general and in particular, the MFSB as semi-governmental bodies. In that regard, this study hopes to fill this gap in the literature by providing some insight on the extent of disclosures noted in the annual reports of the MFSB by taking a more comprehensive assessment of their accountability disclosures.

\section{Methodology}

This study focuses on the annual reports of 2008, a year after the issuance of the TC 4/2007. Annual reports of 2009 onwards were still unavailabe at the time of data collection (i.e. June to December 2010) as they were yet to be tabled to the Parliament. Although there was a total of 118 MFSB in 2008, due to some reasons such as exemption from preparing and/or tabling annual reports granted to certain MFSB, the effective population noted for the current study amounts to only 111 MFSB. Overall, the entire process of obtaining data consumed a period of approximately seven months, duration similar to Dixon et al.'s (1991). The difficulty of getting access to government annual reports has been acknowledged by many other previous authors (e.g. Dixon et al., 1991; Banks and Nelson, 1994).

The current study employs a 110-item disclosure index developed by Abu Bakar (2016) referred to as the Accountability Disclosure Index for the MFSB or ADI, which attempts to measure the extent of accountability disclosures in MFSB annual reports. It represents a good model of MFSB reporting practices. The index was divided into five categories (overview, governance, financial, performance, others) and 24 subcategories.

\section{Results and Discussion}

Overall, a total of 106 annual reports were collected from the 111 MFSB entities which represent 95.5 per cent of the effective population. On average, 52.6 out of 110 items were disclosed representing 47.8 per cent of the total disclosure items. The range of items disclosed by the MFSB is between 27 and 78 (25 and $71 \%$ ), indicating a moderate level of disclosure. This is comparatively lower than prior studies on accountability disclosure in public sector annual reports. Ismail and Abu Bakar (2011), for example, found a 75 per cent index score in their study on Malaysian universities' annual reports. Coy and Dixon (2004), in contrast, found a disclosure score of 66 per cent in their analysis of the annual reports of New Zealand universities for the year 2000.

\subsection{Overview Disclosure Category (8 groups, 38 items)}

The mean for the Overview category is 56.7 per cent (refer to Table 1). Six items were disclosed by more than 90 per 
cent of the MFSB. These items are content page (ADI1), address (ADIS5), role/function/main activities (ADI12), chairman name (ADI18), CEO name (ADI19), and name of board members (ADI32). All these items, except ADI1, are required by TC4/2007 and could thus, constitute the main reason for disclosure by the MFSB.

Table 1. Descriptive Statistics of the Overview Category

\begin{tabular}{|c|c|c|c|}
\hline$\overline{A D I N o}$ & Discosure Item & Frequency $(n=106)$ & Percentage \\
\hline & BACKGROUND OF ANNUAL REPORT (GROUP1) & & \\
\hline 1 & Content page & 106 & $100 \%$ \\
\hline 2 & Index/ glossary & 6 & $5.7 \%$ \\
\hline 3 & Statutory process timeliness: annual report submission to Minister/Parliament & 5 & $4.7 \%$ \\
\hline 4 & $\begin{array}{l}\text { Public accountability timeliness: annual report publication } \\
\text { Mean for Background Of Annual Report }\end{array}$ & 7 & $\frac{6.6 \%}{29.2 \%}$ \\
\hline & ACCESS INFORMATION (GROUP2) & & \\
\hline 5 & Address of registered office & 98 & $92.5 \%$ \\
\hline 6 & Contact information (Telephone/fax/email) & 87 & $82.1 \%$ \\
\hline 7 & Webpage & 90 & $84.9 \%$ \\
\hline 8 & Business hours & 2 & $\underline{1.9 \%}$ \\
\hline & Mean for Access Information & & $65.3 \%$ \\
\hline & BACKGROUND OF STATUTORY BODIES (GROUP3) & & \\
\hline 9 & Year of establishment & 88 & $83.0 \%$ \\
\hline 10 & Parliamentary Act under which MFSB was established & 88 & $83.0 \%$ \\
\hline 11 & Governing ministry & 59 & $55.7 \%$ \\
\hline 12 & Role/ function/ main activities & 97 & $\underline{91.5 \%}$ \\
\hline & Mean for Background of MFSB & & $78.3 \%$ \\
\hline & COMPANY OBJECTIVES AND PHILOSOPHY (GROUP4) & & \\
\hline 13 & Vision and Mission & 93 & $87.7 \%$ \\
\hline 14 & Values/ethics/philosophy & 34 & $32.1 \%$ \\
\hline 15 & Aims/goals/objectives & 90 & $84.9 \%$ \\
\hline 16 & Client charter & 35 & $33.0 \%$ \\
\hline & Mean for Company Objectives And Philosophy & & $\overline{59.4 \%}$ \\
\hline & CORPORATE INFORMATION (GROUP5) & & \\
\hline 17 & Organisation chart & 89 & $84.0 \%$ \\
\hline 18 & Chairman: name & 105 & $99.1 \%$ \\
\hline 19 & Chief Executive: name & 101 & $95.3 \%$ \\
\hline 20 & External auditor & 29 & $27.4 \%$ \\
\hline 21 & Main bank(s) & 17 & $16.0 \%$ \\
\hline 22 & Main lawyer(s) & 4 & $3.8 \%$ \\
\hline 23 & List of main events in the year & 59 & $\underline{55.7 \%}$ \\
\hline & Mean for Corporate Information & & $54.4 \%$ \\
\hline & CHAIRMAN AND CEO MESSAGES (GROUP6) & & \\
\hline 24 & Overall comments on programmes, activities and projects (PAP) of MFSB & 69 & $65.1 \%$ \\
\hline 25 & $\begin{array}{l}\text { Achievements and financial status of PAP of MFSB \& compare with previous } \\
\text { years }\end{array}$ & 57 & $53.8 \%$ \\
\hline 26 & Events that influence the performance of PAP of MFSB & 77 & $72.6 \%$ \\
\hline 27 & Future prospects and corporate strategies & 68 & $64.2 \%$ \\
\hline 28 & Growth and development of PAP & 64 & $60.4 \%$ \\
\hline 29 & Acknowledgement to contributors of the SB success & 76 & $71.7 \%$ \\
\hline 30 & Minister message & 16 & $15.1 \%$ \\
\hline 31 & Chief executive message & 62 & $\underline{58.5 \%}$ \\
\hline & Mean for Chairman And Ceo Messages & & $57.7 \%$ \\
\hline & BOARD OF DIRECTORS (GROUP7) & & \\
\hline 32 & BOD: members' name & 105 & $99.1 \%$ \\
\hline 33 & BOD: secretary & 41 & $38.7 \%$ \\
\hline 34 & BOD: organisation represented & 76 & $71.7 \%$ \\
\hline 35 & BOD: members' term end/start & 68 & $\underline{64.2 \%}$ \\
\hline & Mean for Board Of Directors & & $68.4 \%$ \\
\hline & SENIOR EXECUTIVES (GROUP8) & & \\
\hline 36 & Senior management: name and designation & 91 & $85.8 \%$ \\
\hline
\end{tabular}


37 Senior management: education and qualification

38 Senior management: skils and experience (know-how)

Mean for Senior Executives OVERALL MEAN FOR OVERVIEW CATEGORY
$17.9 \%$

$\underline{6.6 \%}$

$36.8 \%$

$56.7 \%$

Further, six items were disclosed at a rate of less than 10 per cent by the MFSB; index/glossary (ADI2), statutory process timeliness (ADI3), public accountability timeliness (ADI4), MFSB business hours (ADI8), main lawyers (ADI22), and senior management skills and experience (ADI38). Further, the disclosure of senior management skills and experience (ADI38) is much lesser than the findings made by Schneider and Samkin (2008) who found that in the context of New Zealand local authorities, work-related knowledge is disclosed at a rate of 20 per cent.

In terms of groups of disclosure items, on average, the highest disclosure is related to GROUP 3 which relates to information on the background of MFSB with a score of 78.3 per cent. Three out of four items under GROUP 3 have a disclosure level of above 80 per cent. These items are establishment year (ADI9), Parliamentary Act (ADI10), and the main activities of MFSB (ADI12). The last two items are both required under TC4/2007. Disclosure on ADI10 (83\%) is substantially higher than Ismail and Abu Bakar's (2011) study on Malaysian public universities (54.5\%), whereas disclosure rates of main activities (ADI12) (91.5\%) is slightly lower than that of Ismail and Abu Bakar (2011) which found that all public universities disclosed ADI12. In all the MFSB, this information (ADI9, 10, 12) can be found in the first 10 pages of their reports. The group under the Overview category with the lowest disclosure level is GROUP $1(29.2 \%)$ which relates to the background of annual reports. For this group, three out of four items have disclosure levels under seven per cent. These items are index/glossary (ADI2), statutory process timeliness (ADI3), and public accountability timeliness (ADI4).

\subsection{Governance Disclosure Category (4 groups, 17 items)}

The mean for disclosure for Governance is 19 per cent, which is relatively low (refer to Table 2). This result is consistent with the observation made by Ryan and $\mathrm{Ng}(2000)$ who noted that there was a lack of reporting on governance practices by public entities. Only three out of 17 items in this category have scores above 25 per cent. These items are the review and/or appraisal on effectiveness of risk management (ADI54), number of board meetings per year (ADI41), and board of director's remuneration policy or total amount (ADI45). Risk management (ADI54) and the frequency of board meetings (ADI41) are recommended for disclosure by listed companies by the Malaysian Code on Corporate Governance (MCCG). This suggests that the MFSB have taken heed of this advice, perhaps in light of their importance as a mechanism towards achieving good corporate governance. The disclosure level for risk management (ADI54) in this study is found to be higher than the 66 per cent level observed by Herawaty and Hoque (2007). The findings on a board's remuneration policy and amount (ADI45) do not fully support Ryan et al.'s (2002) study which concluded that this information is generally revealed.

Table 2. Descriptive Statistics of the Governance Category

\begin{tabular}{|c|c|c|c|}
\hline ADI No. & Disclosure Item & Frequency $(\mathrm{n}=106)$ & Percentage \\
\hline & BOARD OF DIRECTORS GOVERNANCE (GROUP9) & & \\
\hline 39 & BOD: members' education and qualification & 24 & $22.6 \%$ \\
\hline 40 & BOD: members' skills and experience of nonexecutive director & 21 & $19.8 \%$ \\
\hline 41 & BOD: number of meetings per year & 47 & $44.3 \%$ \\
\hline 42 & BOD: meeting dates & 26 & $24.5 \%$ \\
\hline 43 & BOD: attendance summary & 18 & $17.0 \%$ \\
\hline 44 & BOD: meeting attendance of each individual director & 15 & $14.2 \%$ \\
\hline 45 & BOD: remuneration policy or total amount & 39 & $36.8 \%$ \\
\hline 46 & $\begin{array}{l}\text { BOD: remuneration amount listed by person } \\
\text { Mean of Board Of Directors Governance }\end{array}$ & 2 & $\frac{1.9 \%}{22.6 \%}$ \\
\hline & SENIOR MANAGEMENT GOVERNANCE (GROUP10) & & \\
\hline 47 & SM: remuneration amount of CEO & 4 & $3.8 \%$ \\
\hline 48 & SM: remuneration amount of other senior executives (total or individual) & 10 & $9.4 \%$ \\
\hline 49 & $\begin{array}{l}\text { SM: how nature and amount of remuneration of senior executives is determined } \\
\text { Mean of Senior Management Governance }\end{array}$ & 0 & $\underline{0.0 \%}$ \\
\hline & FINANCIAL MANAGEMENT AND ACCOUNT COMMITTEE (GROUP11) & & \\
\hline 50 & FMAC: members' name & 17 & $16.0 \%$ \\
\hline
\end{tabular}




\begin{tabular}{clcc}
51 & FMAC: required number of meetings & 4 & $3.8 \%$ \\
52 & FMAC: number of meetings & 15 & $14.2 \%$ \\
53 & FMAC: effectiveness of FMAC in handling financial issues & 1 & $\underline{0.9 \%}$ \\
& Mean for FMAC & $8.7 \%$ \\
\hline \multirow{2}{*}{54} & INTERNAL AUDIT (GROUP12) & Review and/or appraisal on effectiveness of risk management & 72 \\
55 & Review/appraisal of internal control systems & 18 & $\underline{17.0 \%}$ \\
& Mean for Internal Audit & $\mathbf{4 7 . 2 \%}$ \\
\hline & OVERALL MEAN FOR GOVERNANCE CATEGORY & $19.0 \%$ \\
\hline
\end{tabular}

None of the MFSB discloses information regarding the amount and the method used for determining the remuneration of senior executives (ADI49). This finding is consistent with that of Herawaty and Hoque (2007) who likewise, noted that the item was the least disclosed under their governance category, with almost half of the Australian government departments had disclosed this item. In comparison to the MFSB, the outcome suggests that the MFSB is taking on a much worse position.

In terms of groups of disclosure items, on average, the group with the highest disclosure is GROUP 12 which is concerned with internal audit information. The two items under this group are based on the MCCG recommendation. One concerns risk management (ADI54) and the other concerns internal control (ADI55). Information on risk management (ADI54) shows high levels of disclosure, consistent with the study made by Ryan and $\mathrm{Ng}$ (2000) which found 72 per cent public agencies in Queensland disclosed this information. The adequate disclosure found in the current study may be attributed to the substantial attention given by the MCCG on this particular issue.

Surprisingly, the results here show that internal control (ADI55) has a disclosure level of only 17 per cent, a finding that is less than that revealed by Ryan and $\mathrm{Ng}(2000)$ who found 83 per cent disclosure on internal control by various public agencies in Queensland. The low level of disclosure of internal control information in the MFSB reports may indicate a relatively low importance attached to internal control function by the MFSB, as compared to Queensland public agencies, for example.

The least disclosed group under the Governance category is GROUP 10 which focused on information on senior management governance (4.4\%). All three items under this group (i.e. ADI47, 48 and 49) have less than 10 per cent disclosure levels. For ADI47 which concerns CEO remuneration amounts (3.8\%), the score is consistent with the findings of Ryan et al. (2002) who found only one council, from three years of study (i.e. 1997 to 1999), had disclosed this information. They concluded that salaries of higher management in local councils are generally not made public. In their study, Ryan et al. found that the scores for disclosure on remuneration of councillors and/or executives decreased over the three years, with a mean of $54 \%$. Results for the amount of remuneration of other senior executives (total or individual) (ADI48) show that 9.4 per cent of the MFSB disclosed the item. This is almost half of the rate found by Schneider and Samkin (2008) where 17 (21\%) out of 82 New Zealand local authorities disclosed the item. Dixon et al. (1991) argued that the importance of breaking down salaries figures is to enable users to identify where an organisation staffing priorities lay. In the context of the current study, the information is also important to determine whether there is any mismanagement of public funds by 'overpaying' senior executives.

\subsection{Financial Disclosure Category (4 groups, 20 items)}

The overall mean for the Financial category is 55.2 per cent (refer to Table 3). All the MFSB disclosed four of the items under this category namely the balance sheet (ADI56), income statement (ADI57), statement of chairman and a board member for the group accounts (ADI62), and statutory declaration by the officer primarily responsible for the financial management (ADI63). This result is similar to that found by Dixon et al. (1991) where the balance sheet and operating statements were disclosed by all seven New Zealand universities. Additionally, four other items (not including the four items above) were disclosed by more than 90 per cent of the MFSB. The items are statement of changes in equity (ADI58), cash flow statement (ADI59), notes to the financial statement (ADI60), and auditor general certificate (ADI61). All these eight items are among the financial items required to be disclosed by the TC4/2007. With regards to the auditor general certificate (ADI61), a study on internet financial reporting of Spain's city councils by Perez et al. (2008) found that only 1.5 per cent of the financial information that was reported annually was accompanied by the corresponding audit certificate. 
Table 3. Descriptive Statistics of the Financial Category

\begin{tabular}{|c|c|c|c|}
\hline ADI No. & Disclosure Item & Frequency $(n=106)$ & Percentage \\
\hline & AUDITED FINANCIAL STATEMENTS (GROUP13) & & \\
\hline 56 & Balance sheet & 106 & $100.0 \%$ \\
\hline 57 & Income statement & 106 & $100.0 \%$ \\
\hline 58 & Statement of changes in equity & 104 & $98.1 \%$ \\
\hline 59 & Cash flow statement & 105 & $99.1 \%$ \\
\hline 60 & Notes to the financial statement & 105 & $\underline{99.1 \%}$ \\
\hline & Mean For Audited Financial Statements & & $\overline{99.2 \%}$ \\
\hline & ACCOMPANYING CERTIFICATE AND STATEMENT (GROUP14) & & \\
\hline 61 & Auditor general certificate & 105 & $99.1 \%$ \\
\hline 62 & Statement of Chairman and a Board member for the Group accounts & 106 & $100.0 \%$ \\
\hline 63 & $\begin{array}{l}\text { Statutory declaration by the officer primarily responsible for the financial mgmt. } \\
\text { Mean for Accompanying Certificate And Statement }\end{array}$ & 106 & $\frac{100.0 \%}{99.7 \%}$ \\
\hline & ANALYSIS OF FINANCIAL PERFORMANCE (GROUP15) & & \\
\hline 64 & Comparison figures/charts: on assets used & 44 & $41.5 \%$ \\
\hline 65 & Comparison figures/charts: on various source of finance & 74 & $69.8 \%$ \\
\hline 66 & Comparison figures/charts: on reserve & 33 & $31.1 \%$ \\
\hline 67 & Comparison figures/charts: on noncurrent liabilities & 19 & $17.9 \%$ \\
\hline 68 & Comparison figures/charts: on sales/receipts and gross profit margin & 62 & $58.5 \%$ \\
\hline 69 & Comparison figures/charts: on surplus/deficit or profit/loss & 48 & $\underline{45.3 \%}$ \\
\hline & Mean for Analysis Of Financial Performance & & $44.0 \%$ \\
\hline & FINANCIAL RATIOS (GROUP 16) & & \\
\hline 70 & Current ratio (Current assets/Current liabilities) & 11 & $10.4 \%$ \\
\hline 71 & Liquidity ratio (Liquid assets/Current liabilities) & 11 & $10.4 \%$ \\
\hline 72 & Debt asset ratio (Total debt/Total assets) & 10 & $9.4 \%$ \\
\hline 73 & Proprietor's ratio (Total equity / total liability) & 6 & $5.7 \%$ \\
\hline 74 & Total equity/total asset & 8 & $7.5 \%$ \\
\hline 75 & Assets turnover ratio & 2 & $1.9 \%$ \\
\hline & Mean for Financial Ratios & & $7.5 \%$ \\
\hline & OVERALL MEAN FOR FINANCIAL CATEGORY & & $55.2 \%$ \\
\hline
\end{tabular}

The group with the greatest disclosure reported on financial statements with accompanying certificates and statements (GROUP14), closely followed by audited financial statements (GROUP13). All items in GROUP14 and 13 are required by the TC4/2007. Furthermore, all items in GROUP13 are also recommended by IPSAS 1 and 2 of IFAC 2 to be provided in the government's annual public financial reports (IFAC, 2011). The finding noted here may explain the very high disclosure level of these two groups. The results from the current study are very much higher than what Caba Perez and Lopez-Hernandez (2009) noted in their study on the annual public financial reports of the central government of MERCUSOR countries (Argentina, Brazil, Paraguay and Uruguay). It was revealed that none of these countries had included all the information in GROUP13 as proposed by IPSAS 1 and 2 of IFAC.

On the other hand, financial ratios (GROUP16) was found to be the least disclosed with a score of only 7.5 per cent. This finding is lower than a study by Stanley et al. (2008) which found that financial ratios are commonly disclosed by Queensland local authorities where 65 per cent of local authorities disclosed them. The disclosure of financial ratios is required by either the TC4/2007 or the GC6/2004 in the annual report and the annual summary report ${ }^{3}$ respectively. The TC4/2007 requires the disclosure of debt assets ratio (ADI72) and assets turnover ratio (ADI75). Regardless of such requirements, the disclosure levels for these two ratios appear to be very low with 9.4 per cent and 1.9 per cent respectively. The other four ratios (i.e. current ratio (ADI70), liquidity ratio (ADI71), proprietors' ratio (ADI73) and ratio on total equity/total fixed asset (ADI74) plus debt assets ratio (ADI72) are required to be disclosed by GC6/2004 in the

\footnotetext{
${ }^{2}$ According to IPSAS 1 and 2 of the IFAC, a complete set of financial statements should include the following statements: (a) statement of financial position - a balance sheet or statement of assets and liabilities; (b) statement of financial performance;

(c) statement of changes in net assets/equity; (d) cash flow statement; and (e) accounting policies and notes to the financial statements. ${ }^{3}$ Annual summary report of MFSB is a 3-page summary on MFSB overall performance in terms of financial management, operational efficiency and effectiveness and output quality to be submitted and tabled in the Cabinet meeting by the respective MFSB Minister Prime Minister's Department. 2004. General circular letter no. 6 of 2004: amendment to the general circular letter no. 1 of 1995 on preparation of annual summary report of the financial status and performance of federal statutory bodies. Kuala Lumpur: Percetakan Nasional Malaysia.
} 
annual summary reports. All these ratios are disclosed by less than 11 per cent of the MFSB.

\subsection{Performance Disclosure Category (4 groups, 20 items)}

The overall mean for the Performance category noted in this study is 57.6 per cent (refer to Table 4), a result that is consistent with Wei et al.'s (2008) study which found a performance accountability disclosure score of 61 per cent. This category is the most disclosed category of information in the index, possibly reflecting the assumption made by the MFSB that performance information interests the public most.

Table 4. Descriptive Statistics of the Performance Category

\begin{tabular}{|c|c|c|c|}
\hline ADI No. & Disclosure Item & Frequency $(n=106)$ & Percentage \\
\hline & KEY PERFORMANCE INDICATORS (GROUP17) & & \\
\hline 76 & Key Performance Indicators & 44 & $41.5 \%$ \\
\hline \multirow[t]{2}{*}{77} & Compare targeted KPI and actual achievement (in figure/percentage) & 29 & $\underline{27.4 \%}$ \\
\hline & Mean for Key Performance Indicators & & $34.4 \%$ \\
\hline & CUSTOMER/ EMPLOYEE SATISFACTION (GROUP18) & & \\
\hline 78 & Customer satisfaction & 18 & $17.0 \%$ \\
\hline 79 & Staff satisfaction & 5 & $4.7 \%$ \\
\hline 80 & No. of complaints received on MFSB & 17 & $16.0 \%$ \\
\hline \multirow[t]{2}{*}{81} & No. of valid complaints resolved & 15 & $\underline{14.2 \%}$ \\
\hline & Mean for Customer/Employee Satisfaction Indicator & & $13.0 \%$ \\
\hline & OVERVIEW OF PROGRAM/ACTIVITIES/PROJECTS (PAP) (GROUP19 & & \\
\hline 82 & Objective and description of each PAP & 101 & $95.3 \%$ \\
\hline 83 & Implementation progress of each PAP & 100 & $94.3 \%$ \\
\hline 84 & Problems encountered in the implementation & 34 & $32.1 \%$ \\
\hline 85 & Factors (internal/external)influencing current performance & 89 & $84.0 \%$ \\
\hline \multirow[t]{2}{*}{86} & Future plans & 66 & $62.3 \%$ \\
\hline & Mean for Overview Of Program/Activities/Projects (Pap) & & $\overline{73.6 \%}$ \\
\hline & PERFORMANCE OF PAP (GROUP20) & & \\
\hline 87 & Input: Financial resources & 84 & $79.2 \%$ \\
\hline 88 & Input: Non-financial resources applied to a PAP & 85 & $80.2 \%$ \\
\hline 89 & Output & 104 & $98.1 \%$ \\
\hline 90 & Impact & 76 & $71.7 \%$ \\
\hline 91 & Efficiency & 31 & $29.2 \%$ \\
\hline 92 & Effectiveness & 84 & $79.2 \%$ \\
\hline 93 & Productivity & 89 & $84.0 \%$ \\
\hline 94 & Compare between actual and target performance & 65 & $61.3 \%$ \\
\hline \multirow[t]{3}{*}{95} & Compare between current and previous year & 85 & $80.2 \%$ \\
\hline & Performance of PAP & & $73.7 \%$ \\
\hline & OVERALL MEAN FOR PERFORMANCE CATEGORY & & $57.6 \%$ \\
\hline
\end{tabular}

Three items show disclosure levels of above 90 per cent, namely the objectives and descriptions of programmes, activities and projects (PAP) (ADI82), implementation progress of each PAP (ADI83), and output of PAP (ADI89). The first two items are required by the TC4/2007 to be disclosed. The third item, on the other hand, was listed as among the top 20 performance items which were perceived to be very important by stakeholders in study by Tooley et al. (2010) on Malaysian local government. Assuming that stakeholders' information requirements from the Malaysian public sector is similar across different types of entities, it may be said that the high disclosure of ADI89 has partly met the stakeholders' information requirement. On the other hand, the least disclosed item under the Performance category is staff satisfaction (4.7\%).

In terms of groups, the group with the highest disclosure level is GROUP 20, which relates to performance of PAP. This is closely followed by GROUP19 (Overview of PAP). Overall, it is a relief to see that information on performance (GROUP 20) is well reported except in the case of the efficiency of PAP (ADI91). The scores obtained for efficiency (ADI91) are much lower than the 69.1 per cent found by Gordon and Fischer (2008) as is the case of US higher institutions. There should be more reporting on efficiency as this item is also among the top 20 items required by stakeholders as identified by Tooley et al. (2002). One possible reason for the nondisclosure of efficiency information here may be attributed to the difficulties in measuring the efficiency itself. In contrast, a comparison between actual and 
target (ADI94) shows a relatively low score when compared to that of Tooley and Guthrie (2007) who found all 17 New Zealand schools studied had provided this information. The findings noted here are also consistent with the study by Marcuccio and Steccolini (2009) which found output measures (60\%) are disclosed more than the input measures (9\%).

On the other hand, the group with the least disclosure level is the customer/staff satisfaction (GROUP18). Within this group, the item showing the highest disclosure, namely customer satisfaction (ADI78) is much lower than Wei et al.'s (2008) study which scored 58 per cent. In addition, the score achieved for ADI78 may not be a favourable situation as a prior study by Tooley et al. (2010) found that customer satisfaction was perceived by Malaysian local government stakeholders as a very important information.

\subsection{Disclosure of Others Items (3 groups, 15 items)}

This category has an overall mean of 34.6 per cent (refer to Table 5). Only one item under this category has a disclosure level of above 80 per cent namely, statistics on staffing (ADI96) which scored 82.1 per cent. This figure is almost similar to the findings of Herawaty and Hoque (2007) who found this item being disclosed by 85.7 per cent of Australian government departments, the most disclosed item under human resource practices.

Table 5. Descriptive Statistics of the Others Category

\begin{tabular}{|c|c|c|c|}
\hline ADI No & Disclosure Item & Frequency $(n=106)$ & Percentage \\
\hline & HUMAN RESOURCE (GROUP21) & & \\
\hline 96 & Statistics on staffing (e.g. total staff, vacancies) & 87 & $82.1 \%$ \\
\hline 97 & Workforce planning, staff turnover and retention & 52 & $49.1 \%$ \\
\hline 98 & Equal opportunity employment (e.g. staff by race/gender/age) & 8 & $7.5 \%$ \\
\hline 99 & Statistics on training and development courses/programmes for staff & 72 & $67.9 \%$ \\
\hline 100 & Achievements/impact of staff training and development activities (general/each) & 23 & $21.7 \%$ \\
\hline 101 & Staff recognition through awards/rewards/titles & 46 & $43.4 \%$ \\
\hline 102 & Staff recognition: Names of awards/titles/rewards recipients & 20 & $18.9 \%$ \\
\hline & Mean for Human Resource & & $\overline{41.5 \%}$ \\
\hline & SOCIO-ENVIRONMENTAL (GROUP22) & & \\
\hline 103 & Internal/external social responsibility efforts/activities & 78 & $72.9 \%$ \\
\hline 104 & Financial information on social responsibility issues (budget/cost) & 50 & $46.7 \%$ \\
\hline 105 & Internal/external environmental protection efforts/activities & 29 & $27.4 \%$ \\
\hline 106 & Financial information on environmental issues (budget/cost) & 5 & $4.7 \%$ \\
\hline & Mean for socio-environmental & & $\overline{37.9 \%}$ \\
\hline & MAIN ASSETS (GROUP23) & & \\
\hline 107 & List of main assets: location & 20 & $18.9 \%$ \\
\hline 108 & List of main assets: ownership & 15 & $14.2 \%$ \\
\hline 109 & List of main assets: size (area) & 20 & $18.9 \%$ \\
\hline 110 & List of main assets: description/type & 27 & $25.5 \%$ \\
\hline & Mean for Main Assets & & $19.3 \%$ \\
\hline & OVERALL MEAN FOR OTHERS CATEGORY & & $34.6 \%$ \\
\hline
\end{tabular}

The least disclosed item under this category is the financial information on environmental issues (ADI106) with a score of 4.7 per cent. This is somewhat consistent with studies in other settings such as in the case of Joseph (2010) who found that only three (3) per cent of Malaysian local governments reported this information. Following this, the next least disclosed item after ADI106 is information on equal employment opportunity (ADI98) with a disclosure level of only 7.4 per cent. The low disclosure found in this study is far below the findings made by Schneider and Samkin (2008) who reported a mean score of 2.1 out of 5 for this item among 82 New Zealand local authorities. Notably, all the three groups under this category (i.e. human resource, socio-environmental and main assets) were disclosed by less than 45 per cent of the MFSB. The least disclosed group concerns properties or main assets (GROUP23) (19.3\%). The finding is much lower than what was found by Tooley and Guthrie (2007) where information on property was disclosed by all 17 New Zealand secondary schools. Here, it can be said that the requirements of TC4/2007 on the disclosure of the MFSB main assets and properties are not closely observed by majority of the MFSB. 


\section{Conclusion}

This research is concerned with the extent of disclosure of accountability information made in the annual reports of the MFSB. To achieve this objective, an analysis was conducted on the 2008 annual reports of 106 MFSB using a disclosure index referred to as ADI which consisted of 110 items divided over 5 categories. The main results revealed that the MFSB provided a moderate level of disclosure in their annual reports. By category, the highest disclosure is found in the Performance category, followed by Overview, Financial, Others (i.e. human resource, socio-environmental and main assets) and finally Governance. This finding suggests that the MFSB are more willing to share their performance information but are less committed in exhibiting their governance issues. Stakeholders may obtain a moderate level of performance, general overview, financial information of MFSB by reading the respective annual reports. The MFSB, however, do not sufficiently provide governance information. The low governance-related information is expected as the disclosure items for this category were partly drawn from MCCG, a code which is not directed towards a government agency such as the MFSB. Despite this, it is argued that since the MFSB are expected to carry out government policies professionally and effectively through various programmes and activities (National Audit Department, 2008), necessary measures such as being more open in its disclosure of governance information is necessary and appropriate. This allows for a necessary scrutiny and more effective action of boards, as pointed out in the report by the Cadbury Committee (1992). The importance of governance disclosure as described here suggests much opportunity for the MFSB to pursue with greater effort towards maintaining more governance disclosure in their annual reports. Further, given that other categories of disclosure such as Performance and Overview are higher on their level of disclosure as compared to Financial disclosure, it would appear that the prime objective of the MFSB reporting may not simply be to meet the needs of those with a commercial relationship with them (i.e. decision usefulness). Rather, it caters to a wider range of interested users, hence is consistent with the public accountability paradigm as explained earlier. However, it is noted that the MFSB has not fully observed high extent of disclosure. More efforts hence, need to be done to ensure that the MFSB annual reporting is effective as it is one of the many mechanisms by which public accountability agenda can be achieved and fulfilled. The practice may also enhance its due importance among public entities.

As explained earlier, the disclosure index developed (i.e. ADI) represents a good model of MFSB reporting practices. The strength of the index not only enhances the usefulness of the results obtained, but may also serve as the reason to provide a review and revision of the existing TC4/2007 such as incorporating some of the ADI items. These ADI items would be very useful as benchmarks for the MFSB to adhere to closely in their future reporting cycles. Doing so would enable the MFSB, in particular, and the government, in general, to be closer with the international public sector reporting practice as a pledge of commitment towards transparency and accountability. In fact, prior studies such as Allen and Sanders (1994) has established that standard assessment activities, such as revising the Circular in this context, is a contributing factor towards greater disclosure. It also increases the possibility for the index to be applied by future research in different settings both locally and internationally.

Despite the strength and contributions of the study, the results, however, need to be interpreted with caution. As the study is related to the 2008 annual report, which represent only a section of the year after the TC4/2007 was published and implemented (i.e. year 2007), the results found may be influenced by the adjustment or learning process. Thus, the MFSB may inadvertently, still be in the process of familiarising themselves to the new circular. In addition to that, the items included in the index - based on certain considerations - are presumed to be the information required by MFSB stakeholders. However, notably, it could be also that a few of these items are not representing the stakeholders' actual needs for information. Future studies therefore, may be interested in conducting a survey on the perceived usefulness of the ADI items among various stakeholders. To allow for a more comprehensive insight on public sector disclosure both in Malaysia and other countries, future research may apply ADI to other government bodies in Malaysia and abroad such as the state statutory bodies, local authorities, and federal and state departments. This will also allow for the external validation of the index itself. Lastly, future research may conduct analysis on factors influencing disclosure as propogated by Abu Bakar and Saleh (2011) and Abu Bakar and Saleh (2015). Additionally, conducting interviews with annual report preparers so as to obtain insights on the reasons for disclosure and nondisclosure of accountability information to understand their motivation and/or reluctance towards disclosure would also be beneficial.

This study, it is hoped, has paved the way for future researchers to investigate the issue of the disclosure of accountability information. It is also hoped that the study has provided valuable input for relevant authorities to formulate relevant policies on disclosure requirements, if not to improve current policies particularly, for the MFSB, towards enhancing transparency and accountability. This is important as quality policy formulation and decision making requires objective, factually-based knowledge and policy expertise in order to safeguard public interests and promote the wellbeing of a particular nation. Additionally, it is also hoped that the study contributes towards the knowledge and 
literature on public sector reporting.

\section{References}

Abu Bakar, N. B. 2016. Developing an accountability disclosure index for statutory bodies: a proposal. Research Journal of Applied Sciences, Engineering and Technology (forthcoming).

Abu Bakar, N. B., \& Saleh, Z. 2011. Incentives for disclosure of accounting information in public sector: A Literature Survey. International Research Journal of Finance and Economics, 75(October): 24-38.

Abu Bakar, N. B., \& Saleh, Z. 2015. Development of research on factors influencing public sector disclosure. Asian Journal of Business and Accounting, 8(2): 155-184.

Abu Bakar, N. B., Saleh, Z., \& Mohamad, M. H. S. 2011. Enhancing Malaysian public sector transparency and accountability: lessons and issues. European Journal of Economics, Finance and Administrative Sciences, 31(April): 133-145.

Abu, M. F., Aziz, A. A., \& Ahmad, S. N. S. 2012. Annual report mandatory disclosures in Malaysian federal statutory bodies 2012 IEEE Symposium on Business, Engineering and Industrial Applications.

Allen, A., \& Sanders, G. D. 1994. Financial disclosure in US municipalities: has the governmental accounting standards board made a difference? Financial Accountability \& Management, 10(3): 174-193.

Azis, S. 2008. The performance reporting practices of Malaysian federal government statutory bodies: An evaluation of accountability development. Unpublished Masters thesis. International Islamic University Malaysia, Kuala Lumpur.

Banks, W., Fisher, J., \& Nelson, M. 1997. University accountability in England, Wales, and Northern Ireland: 1992-1994. Journal of International Accounting, Auditing and Taxation, 6(2): 211-226.

Banks, W., \& Nelson, M. 1994. Financial disclosures by Ontario universities: 1988-1993. Journal of International Accounting, Auditing and Taxation, 3(2): 287-305.

Blanco, H., Lennard, J., \& Lamontagne, S. 2011. Annual reporting and accountability by municipalities in Canada: An Empirical Investigation. Accounting Perspectives, 10(3): 195-224.

Boyne, G., \& Law, J. 1991. Accountability and local authority annual reports: the case of Welsh district councils. Financial Accountability \& Management, 7(3): 179.

Caba Perez, C., \& Lopez-Hernandez, A. M. 2009. Governmental financial transparency in MERCOSUR member countries. International Review of Administrative Sciences, 75(1): 169-181.

Cadbury Committee. 1992. Report of the committee on the financial aspects of corporate governance. London: Gee and Co. .

Coy, D., \& Dixon, K. 2004. The public accountability index: crafting a parametric disclosure index for annual reports. British Accounting Review, 36: 79-106.

Coy, D., Dixon, K., \& Tower, G. 1993. The annual report of tertiary education institutions: Quality, timeliness and distribution, Working paper. Hamilton: University of Waikato.

Coy, D., Fischer, M., \& Gordon, T. 2001. Public accountability: a new paradigm for college and university annual reports. Critical Perspectives on Accounting, 12(1): 1-31.

Dixon, K., Coy, D., \& Tower, G. 1991. External reporting by new zealand universities 1985-1989: improving accountability. Financial Accountability \& Management, 7(3): 159.

Ferlie, E., \& Pollitt, C. (Eds.). 2005. The Oxford handbook of public management. Oxford: Oxford University Press.

Gordon, T. P., \& Fischer, M. 2008. Communicating performance: the extent and effectiveness of performance reporting by U.S. colleges and universities. Journal of Public Budgeting, Accounting \& Financial Management, 20(2): 217-255.

Guthrie, J. 1993. Australian public business enterprises: analysis of changing accounting, auditing and accountability regimes. Financial Accountability and Management, 9(2): 101-114.

Herawaty, M., \& Hoque, Z. 2007. Disclosure in the annual reports of Australian government departments: A research note. Journal of Accounting \& Organizational Change, 3(2): 147 - 168.

Ho, S. S. M., \& Shun Wong, K. 2001. A study of the relationship between corporate governance structures and the extent of voluntary disclosure. Journal of International Accounting, Auditing and Taxation, 10(2): 139-156.

Hood, C. 1995. The 'New Public Management' in the 1980s: variations on a theme. Accounting, Organizations and Society, 20(2/3): 93109.

Hyndman, N., \& Andersen, R. 1995. The use of performance information in external reporting: an empirical study of UK executive agencies. Financial Accountability and Management 11(1): 1-17.

Hyndman, N., \& Anderson, R. 1998. Performance Information, Accountability and Executive Agencies. Public Money and Management April-June: 23-30.

IFAC. 2011. Handbook of International Public Sector Accounting Pronouncements - Volume I International Federation of Accountants.

Ijiri, Y. 1983. On the accountability-based conceptual framework of accounting. Journal of Accounting and Public Policy and Administration, 2: 75-81.

Ismail, S., \& Abu Bakar, N. B. 2011. Reporting practices of Malaysian public universities: the extent of accountability disclosure. African Journal of Business Management, 5(15): 6366-6376.

Ismail, S., \& Abu Bakar, N. B. 2015. Annual reports of Malaysian public universities: the extent of compliance and accountability. IPN Journal of Research and Practice in Public Sector Accounting and Management, 5(2015):1-20.

Janet, L. 2006. Performance reporting by Australian government trading enterprises: an empirical study 1998-2002. Australian 
Accounting Review, 16(2): 34.

Joseph, C. 2010. Content analysis of sustainability reporting on Malaysian local authorities websites. Journal of Administrative Sciences, 7(1): 101-125.

Marcuccio, M., \& Steccolini, I. 2005. Social and environmental reporting in local authorities. Public Management Review, 7(2): 155-176.

Marcuccio, M., \& Steccolini, I. 2009. Patterns of voluntary extended performance reporting in Italian local authorities. International Journal of Public Sector Management, 22(2): 146-167.

McCrae, M., \& Aiken, M. 1988. Financial accountability of statutory authorities in Australia. Financial Accountability \& Management, 4(3): 191-212.

Nelson, J. D., \& et al. 1997. A comparison of university accountability in Australian and Canada. Journal of Contemporary Issues in Business \& Government, 4(1): 36-46.

Nelson, M., Banks, W., \& Fisher, J. 2003. Improved accountability disclosures by Canadian universities. Canadian Accounting Perspectives, 2(1): 77-107.

Patrizio, M. 2010. Accountability in the new public sector: a comparative case study. International Journal of Public Sector Management, 23(7): 632-646.

Pendlebury, M., Jones, R., \& Karbhari, Y. 1994. Developments in the accountability and financial reporting practices of executive agencies. Financial Accountability and Management, 10(1): 33-46.

Perez, C. C., Bolivar, M. P. R., \& Hernandez, A. M. L. 2008. e-Government process and incentives for online public financial information. Online Information Review, 32(3): 379-400.

Prime Minister's Department. 2004. General circular letter no. 6 of 2004: amendment to the general circular letter no. 1 of 1995 on preparation of annual summary report of the financial status and performance of federal statutory bodies. Kuala Lumpur: Percetakan Nasional Malaysia.

Rutherford, B. A. 2000. The reconstruction and presentation of performance indicators in executive agency external reports. Financial Accountability and Management, 16(3): 225-249.

Ryan, C., \& Ng, C. 2000. Public sector corporate governance disclosures: an examination of annual reporting practices in Queensland. Australian Journal of Public Administration, 59(2): 11-23.

Ryan, C., Stanley, T., \& Nelson, M. 2002. Accountability disclosures by Queensland local government councils: 1997-1999. Financial Accountability and Management, 18(3): 261-289.

Samaratunge, R., Alam, Q., \& Teicher, J. 2008. Public sector reforms and accountability: The case of south and Southeast Asia. Public Management Review, 10(1): 101-126.

Schneider, A., \& Samkin, G. 2008. Intellectual capital reporting by the New Zealand local government sector. Journal of Intellectual Capital, 9(3): 456 - 486.

Taylor, J. 2006. Statutory bodies and performance reporting: Hong Kong and Singapore experience. Public Organization Review 6: 289304.

Tooley, S., Hooks, J., \& Basnan, N. 2010. Performance reporting by Malaysian local authorities: Identifying stakeholder needs. Financial Accountability \& Management, 26(2): 103-133.

Wei, T. L., Davey, H., \& Coy, D. 2008. A disclosure index to measure the quality of annual reporting by museums in New Zealand and the UK. Journal of Applied Accounting Research, 9(1): 29 - 51. 